\title{
Further records and new data on the occurrence of Martyniaceae in Tunisia and North Africa
}

\author{
Ridha El Mokni ${ }^{1,2}$ (])
}

Key words: Proboscidea, Lamiales, new records, Alien flora, Tunisia.

Ključne besede: Proboscidea, Lamiales, novi zapisi, tujerodna flora, Tunizija.

Received: 27.7 .2020

Revision received: 29. 4. 2021

Accepted: 3. 5. 2021

\begin{abstract}
Proboscidea louisianica (Miller) Thell. (Martyniaceae) is newly reported for the flora of Tunisia and North Africa as a naturalised alien. Extensive field investigations in northern Tunisia allowed the discovery of three populations of P. louisianica (Miller) Thell. consisting of 18 individuals found at the edges of "Oued Béja" and at roadside within an irrigated land in Nabeul region, where plant specimens were in flowers and fruits. Moreover, further sites were recorded for another member of the family Martyniaceae (Ibicella lutea (Lindl.) Van Eselt.), already reported and known in Tunisia and Algeria within North Africa. Additional information for both species on their current distribution areas and their habits are provided. Details of their morphological and distinguishing features are illustrated.

\section{Izvleček}

Vrsta Proboscidea louisianica (Miller) Thell. (Martyniaceae) je nova naturalizirana tujerodna vrsta rastlinstva Tunizije in Severne Afrike. S pomočjo obsežnih terenskih raziskav v severni Tuniziji smo odkrili tri populacije vrste P. louisianica (Miller) Thell., ki jih je sestavljalo 18 osebkov na robovih "Oued Béja” in ob cesti med namakanimi polji v regiji Nabeul, kjer so rastline cvetele in plodile. Poleg tega smo zabeležili dodatna rastišča druge vrste iz družine Martyniaceae (Ibicella lutea (Lindl.) Van Eselt.), katere prisotnost je že poznana iz Tunizije in Alžirije v Severni Afriki. Podali smo dodatne informacije o njunem trenutnem arealu razširjenosti in rastiščih in prikazali podrobnosti o njunih morfoloških in razlikovalnih značilnostih.
\end{abstract}




\section{Introduction}

Alien plants are the species that spread due to intentional or unintentional human involvement, beyond the limits of its native geographic range into a given geographical unit where they do not naturally occur (Pyšek et al. 2004, Richardson et al. 2011). In North Africa, published information regarding the naturalisation and expansion of alien plants has a substantial history. Most of the expanding species are ornamentals, originally deliberately introduced by humans (Le Floc'h et al. 1990, Vilà et al. 1999). During the past two decades and even more recently, the knowledge on the non-native flora of Tunisia and North Africa significantly increased (see e.g., El Mokni \& Domina 2018, 2020, El Mokni \& Verloove 2017, 2019a, 2019b, El Mokni et al. 2019, 2020, El Mokni \& Iamonico 2018a, 2018b, 2019, 2020, El Mokni 2018, 2019, 2020, Iamonico \& El Mokni 2020, Sukhorukov et al. 2016, 2018, 2019, Sakhraoui et al. 2016, 2019a, 2019b, Chelghoum et al. 2020). Information about alien plants within Martyniaceae family in North Africa is mostly recent and still scarce (see Dobignard \& Chatelain 2012, El Mokni et al. 2012, Belkassam et al. 2020, Rebbas, 2020).

Martyniaceae is a small family that counts five genera (Craniolaria L., Holoregmia Nees, Ibicella (Stapf) Van Eselt., Martynia L., Proboscidea Schmidel) and ca. 16 species with a distribution area restricted to the New World (Ihlenfeldt 2004, Mabberley 2008, Gutierrez 2012). The family is closely similar to Pedaliaceae, a family from the Old World, and both have been combined as a single family in the past (Gutierrez 2012). However more recently, molecular data showed their distinctiveness (APG IV 2016). The most distinguishing character of the Martyniaceae family is its fruits shape which terminate in an upwardly-curved beak which may be longer (mainly in both genera Ibicella and Proboscidea) or shorter (for the other genera) than the fruit body (Thieret 1977).

The present contribution aims at improving the botanical knowledge about Martyniaceae family in Tunisia and North Africa and updating data on the status and the distribution area of its reported both taxa.

\section{Materials \& Methods}

Floristic field investigations were undertaken since the spring of 2008 within northern Tunisia (North Africa). Digital photographs and GPS coordinates were taken in the field with a camera "Nikon-COOLPIX P520". Identification of the specimens was done according to Ihlenfeldt (2004), Wetherwax \& Heckard (2012) and ICPS
(2020). The nomenclature follows IPNI (2020) and Euro+Med PlantBase (2020). The actual status of naturalization for each taxon is assessed based on literature analysis (cf. Pyšek et al. 2004). Voucher specimens are conserved in the personal herbarium of Ridha El Mokni (Herb. El Mokni!) deposited at the Faculty of Sciences of Bizerta (Fac. Sc. Bizerta) and since 2015 at the Faculty of Pharmacy of Monastir (Fac. Ph. Monastir).

\section{Results \& taxonomic notes}

Within Martyniaceae, two species and two genera are till now known to non-native flora of North Africa with confirmation of their status (as well-established aliens) for both. Among them, one genus and one species (Proboscidea louisianica (Miller) Thell.) are here firstly cited for Tunisian non-native flora. As concern Ibicella lutea (Lindl.) Van Eselt., more records are here reported for the first time and therefore a new area of occurrence is newly assigned for North Africa. A discriminative key to both genera known in North Africa within the Martyniaceae family is also here proposed.

Martyniaceae Horan., Char. Ess. Fam.: 130. 1847

Key to the genera within Martyniaceae known in North Africa

Sepals free, corolla pale to deep yellow. Fruit bristly throughout......................................................Ibicella. Sepals connate, corolla cream to pinkish, often blotched with purple. Fruit crested above only...........Proboscidea.

1. Genus Ibicella Van Eselt. in Techn. Bull. New York Agric. Exp. Sta., Geneva 149: 31. 1929

Ibicella is a genus of few species, native to warm-temperate and tropical regions of central South-America from Bolivia, south Brazil to north Argentina (Gutierrez 2012). Three species are known (I. lutea (Lindl.) Van Eselt., $I$. nelsoniana (Barb. Rodr.) Van Eselt. and I. parodii Abbiatti, The Plant List 2020). Among them I. lutea (Lindl.) Van Eselt. is sometimes cultivated as an ornamental (mostly for its peculiar fruits). It locally occurs as a weed and naturalised elsewhere (Ihlenfeldt 2004).

Ibicella lutea (Lindl.) Van Eselt., New York Agric. Exp. Sta. Techn. Bull. 149: 34 (1929) $\equiv$ Martynia lutea Lindl., Bot. Reg. 11: t. 934 (1825).

Morphology: For a detailed description, see El Mokni et al. (2012), Wetherwax \& Heckard (2012) and Belkassam et al. (2020). Easily identified by its crowded inflorescence generally exceeded by leaves and its flowers with free sepals and yellow corolla, often with orange tinge (Figure 1). 

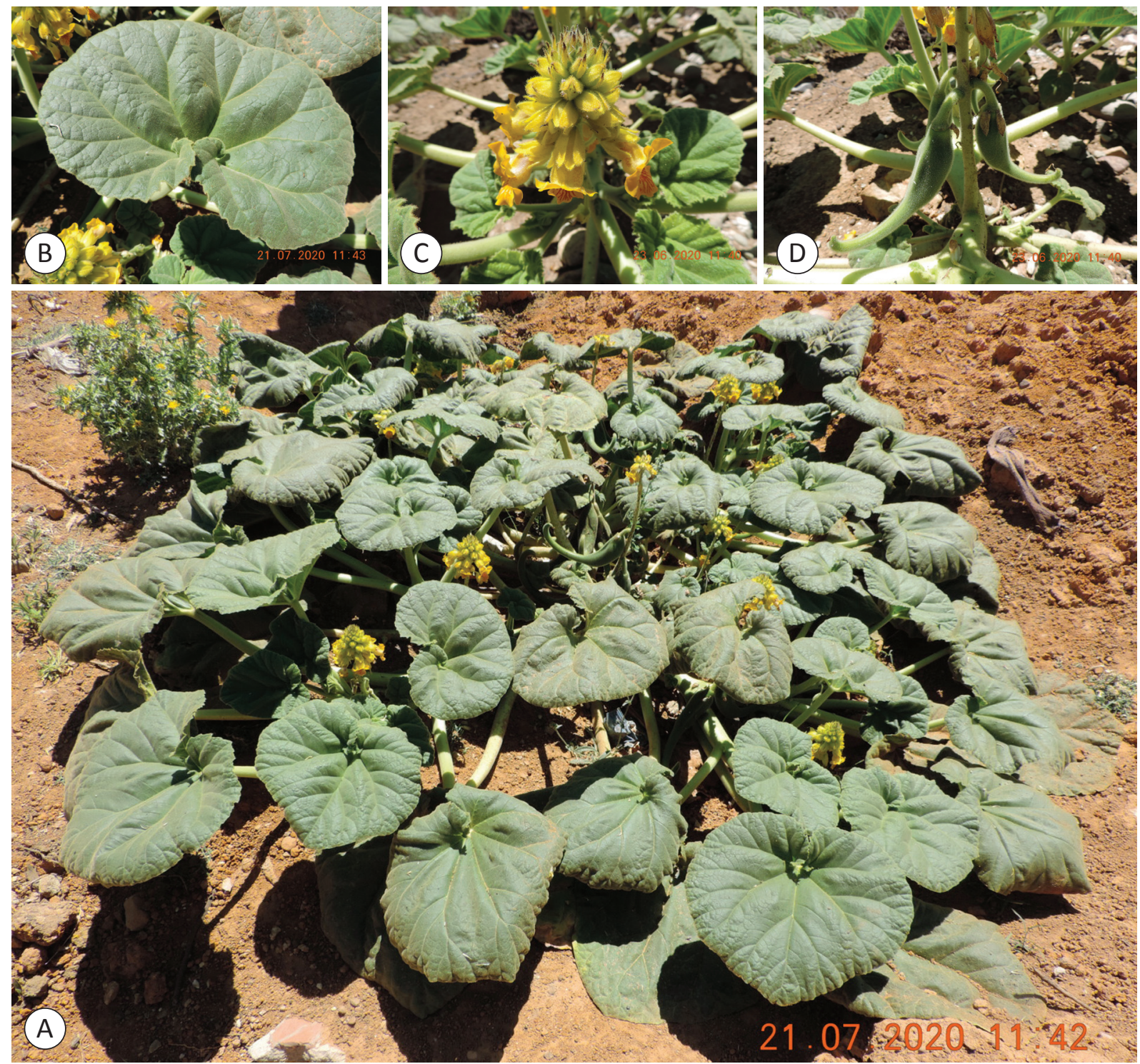

Figure 1: Ibicella lutea in Tunisia. A: habit of the plant in its habitat; B: detail of leave; C: inflorescence with numerous flowers showing free sepals and yellow corolla; D: typical shape fruits which terminate in an upwardly-curved beak (Jendouba, NW Tunisia; 23.6.2020 and 21.7.2020). Photos by Ridha El Mokni.

Slika 1: Ibicella lutea v Tuniziji. A: rastline na rastišču; B: detajl lista; C: socvetje s številnimi cvetovi, ki prikazujejo proste čašne liste in rumene venčne liste; D: značilno navzgor ukrivljeni plodovi (Jendouba, SZ Tunizija; 23.6.2020 in 21.7.2020). Fotografije: Ridha El Mokni.

Flowering period: June-July(-September), Fruiting period: July to August (-October).

Notes on general distribution: For a detailed worldwide distribution, see El Mokni et al. (2012) and Belkassam et al. (2020).

Occurrence in North Africa (Figure 2) and status of naturalization:

Tunisian subpopulations/populations of Ibicella lutea were found in three main localities (Bouhertma, Fernana-
"Oued Saboun" and "Ain Harrath") within Fernana region, Jendouba governorate (Wilaya). Population of Bouhertma remain the largest population with more than 30 scattered mature individuals (up to $3 \mathrm{~m}$ wide) within an area of about 10 ha on the edges of the river crossing the region towards the dam of Bouhertma. The other two subpopulations occur in few individuals (2-5) within the edge of "Oued Saboun" in Fernana and near a water seepage in "Ain Harrath". Each population is occupying an area that cannot exceed 1 ha. 


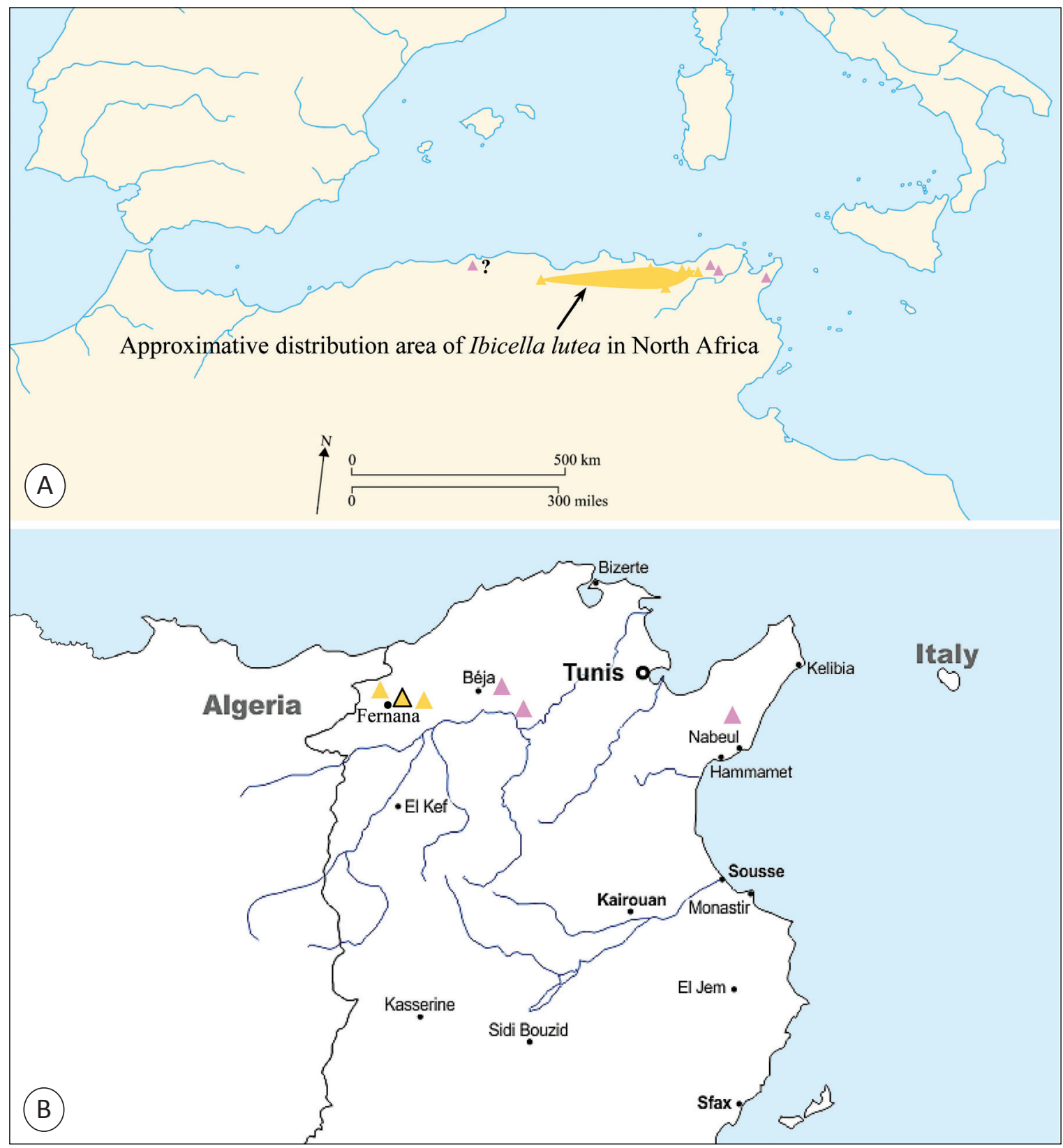

Figure 2: Maps of Martyniaceae occurrence. A: approximative area of distribution for Ibicella luted (in yellow area and triangles), and presence of Proboscidea louisianica (in pink triangles) within North Africa, appointment for Algeria is not precise due to insufficient data; B: detailed appointments for $I$. lutea (in yellow triangles) with two new sites (triangles without black contour) and three new appointments for $P$. louisianica (in pink triangles) within Tunisian territory.

Slika 2: Zemljevidi razširjenosti vrst družine Martyniaceae. A: približno območje razširjenosti vrste Ibicella lutea (rumeno območje in trikotniki) in prisotnost vrste Proboscidea louisianica (rožnati trikotniki) v Severni Afriki. Prikaz za lokacijo v Alžiriji je približen zaradi nenatančnosti podatkov; B: natančne lokacije za vrsto I. lutea (rumeni trikotniki) z dvema novima lokalitetama (trikotniki brez črnega obrisa) in tremi novimi podatki za vrsto $P$. Louisianica (roza trikotniki) v Tuniziji.

Algerian subpopulations/populations of I. lutea were found in three wilaya (Annaba, Béjaïa and Tissemsilt). The largest population was observed in Akbou region (Wilaya of Béjaïa) with more than 50 individuals (Belkassam et al. 2020). Both other subpopulations counting about 10 individuals are far away to the east, near the Tunisian-Algerian border.

As the taxon was firstly reported since 1980 in Algeria and only since 2009 in Tunisia (El Mokni et al. 2012) and remain in good populations till 2020 and according 
to Pyšek et al. (2004) criteria and categorisation, Ibicella lutea can be considered as a well-established (naturalized) alien species in Tunisia, in Algeria and therefore in North Africa. The species could be considered as occurring in one established extended population from Tissemsilt (in Algeria) to Fernana (in Tunisia) (see Figure 2).

Specimina Visa: TUNISIA: Jendouba, FernanaBouhertma, on the edges of the river crossing the region towards the dam of Bouhertma, 36 $41^{\circ} 35^{\prime \prime} \mathrm{N}$, 008 30'30" E, 235 m a.s.l., 23 June 2020, El Mokni s.n. (Herb. El Mokni. - Fac. Ph. Monastir); Jendouba, Fernana-"Ain Harrath", near a water seepage, 36 39'49" N, $008^{\circ} 41^{\prime} 35^{\prime \prime}$ E, $475 \mathrm{~m}$ a.s.l., 21 July 2020, El Mokni s.n. (Herb. El Mokni. - Fac. Ph. Monastir); Jendouba, Fernana-"Oued Saboun", on the edge of the river, 36 39'49" N, 008 $41^{\circ} 35^{\prime \prime}$ E, 270 m a.s.l., 21 July 2020, El Mokni s.n. (Herb. El Mokni. - Fac. Ph. Monastir).

2. Genus Proboscidea Schmidel, Icon. Pl., Ed. Keller 49, tt. 12, 13 (1763).

Proboscidea is a genus of several species, all native to the warmer parts of the Americas and that spread naturally from the south of America to Mexico (Ihlenfeldt 2004, Gutierrez 2012). Its center of diversity lies in the southwestern USA. and Mexico. About ten species (P. altheifolia (Benth.) Decne., P. arenaria (Engelm.) Decne., P. fragrans (Lindl.) Decne., P. louisiana (Mill.) Thell., P. louisianica (Mill.) Thell., P. parviflora (Wooton) Wooton \& Standl., P. sabulosa Correll, P. sinaloensis Van Eselt., P. spicata Correll, P. triloba (Schltdl. \& Cham.) Decne) are accepted by The Plant List (2020). Few species are cultivated as ornamentals (Knees 2000, Jäger et al. 2008) of which P. louisianica (Mill.) Thell. is known as naturalised elsewhere (Ihlenfeldt 2004).

Proboscidea louisianica (Mill.) Thell., Mém. Soc. Sci. Nat. Math. Cherbourg 38: 480 (-481) (1912) झ Martynia louisianica Mill., Gard. Dict., ed. 8. erratum, Martynia no. 3 (1768).

Morphology (Figure 3): a hairy annual plant with prostrate stems (up to $1 \mathrm{~m}$ long); taproot in width equal or almost to stem base. Leaves are velvety, blade generally 5 to $20 \mathrm{~cm}$ wide, broad-triangular, cordiform to round, entire to shallowly indented, wavy-edged. Inflorescences crowded, 20 to 40-flowered, exceeding leaves. Flowers clustered in axillar racemes are trumpet-shaped; calyx 5-lobed with connate sepals, the three lowers are much longer than the two uppers; corolla pink, with more or less purple tinge, darker markings. Fruit is a dehiscent capsule that appears later in summer; body 1.5 to $3 \mathrm{~cm}$ wide, narrowly ovate, almost $10 \mathrm{~cm}$ in length ended in a beak. Seeds are numerous: 7 to $9 \mathrm{~mm}$ long. (cf. Stànescu 2009, Wetherwax \& Heckard 2012).

Flowering period: June-July, Fruiting period: July to August.

Notes on general distribution: Proboscidea louisianica has an unclear native range, but it is generally accepted that most probably area is Mexico and the southwestern of the USA (cf. Gutierrez 2012). It was introduced elsewhere in the European and Mediterranean countries and for the most part established in Portugal and Spain (Martín Madrigal \& Fernández González 2000, Conca et al. 2002), south France (Le Bourgeois et al. 2017), Italy (Raab-Straube 2018+), Belgium (Verloove 2020), Greece (Raus \& Raabe 2016: 429-430), Turkey (Sevgi et al. 2017), South Russia and Caucasica (Greuter et al. 1989:240, Czerepanov 1995:315, Paiva et al. 2001:24), Australia (Thieret 1977, Parsons and Cuthbertson 2001).

\section{Occurrence in Tunisia, in North Africa (Figure 2) and status of naturalization:}

In North Africa, the species was reported till now only from Algeria as casual alien/weed (Raab-Straube 2018+, APD 2020). It is here its first report from Tunisia and second one in North Africa. Tunisian subpopulations/ populations of Proboscidea louisianica were found in three localities within Béja and Nabeul regions. Populations within Béja region occur in aggregated individuals (5-13) within the edges of "Oued Béja". Each population is occupying an area of about 2 ha. The other subpopulation has only three individuals within an area that cannot exceed $100 \mathrm{~m}^{2}$, near a water seepage in Nabeul region.

As the first record of the taxon return to 2008 in Tunisia (Béja, "Oued Béja" towards "Gasr Mezouar") (El Mokni R., perso. obs. 18.06.2008) and more populations with fruiting individuals were recorded in 2020 and according to Pyšek et al. (2004) criteria and categorisation, Proboscidea lonisianica is here assigned as naturalized alien species in Tunisia and therefore in North Africa.

Taxonomic note: once the infraspecific taxonomy of Bretting (1983) is adopted, the Tunisian populations can be allocated to Proboscidea louisianica (Mill.) Thell. subsp. louisianica.

Specimina Visa: TUNISIA: Béja, on the edges of "Oued Béja", 36 44'37" N, 009¹2'24" E, 185 m a.s.l., 18 June 2008, El Mokni s.n. (Herb. El Mokni. - Fac. Sc. Bizerta); Béja, on the edges of "Oued Béja", 36 37'53" N, $009^{\circ} 14^{\prime} 01^{\prime \prime}$ E, 135 m a.s.l., 22 July 2020, El Mokni s.n. (Herb. El Mokni. - Fac. Ph. Monastir). 

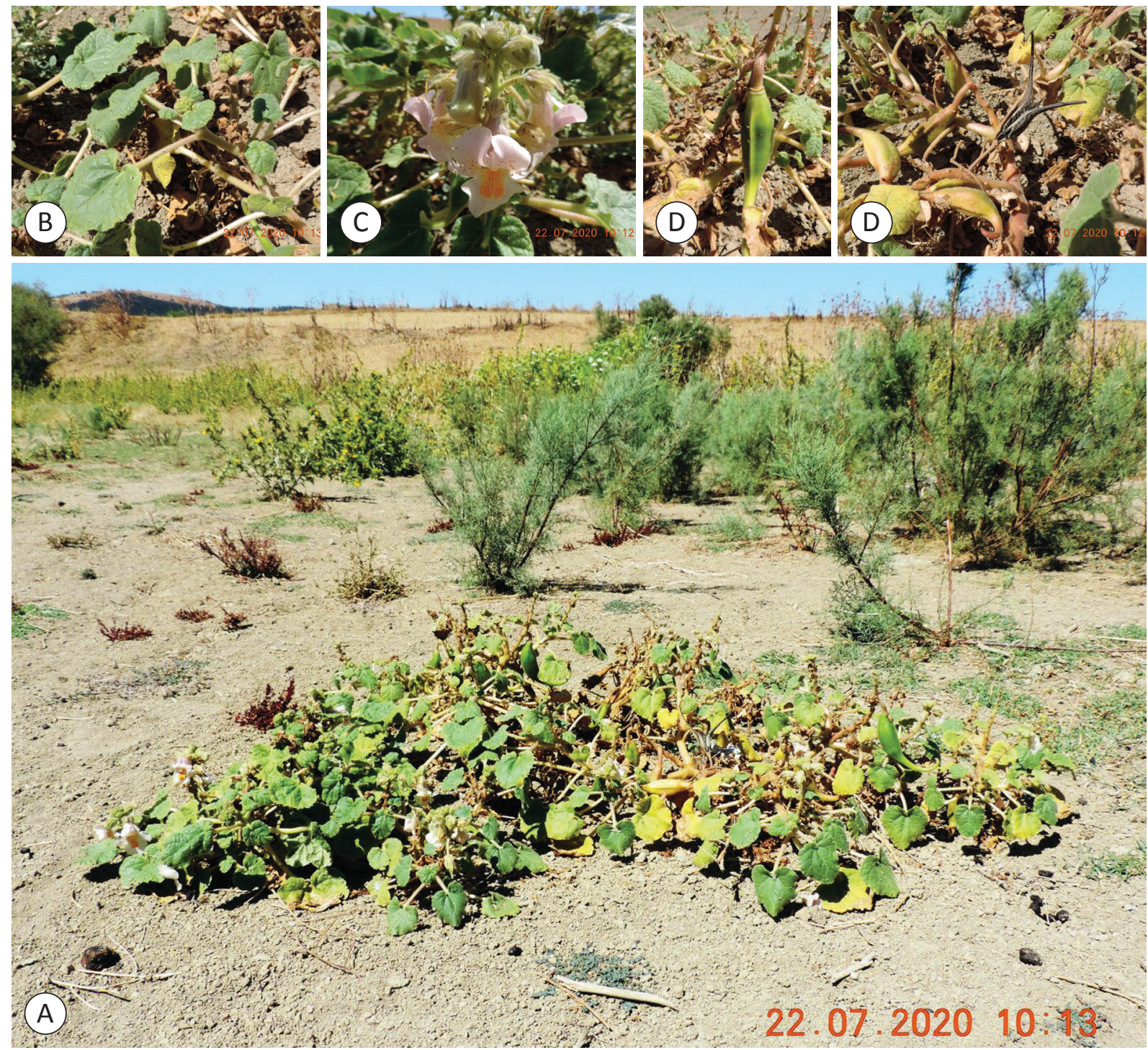

Figure 3: Proboscidea louisianica in Tunisia. A: habit of the plant in its habitat; B: detail of leaves; C: inflorescence with numerous flowers showing connate sepals and cream to pinkish blotched with purple corolla; D: typical shape fruits with long horns; E: mature and dehiscent fruits. (Béja, NW Tunisia; 22. 07. 2020). Photos by Ridha El Mokni.

Slika 3: Proboscidea louisianica v Tuniziji. A: rastline na rastišču; B: detajl lista; C: socvetje s številnimi cvetovi, z zraslimi čašnimi listi in kremastorožnatimi venčnimi listi z vijoličnimi lisami; D: značilno oblikovani plodovi z dolgimi rožički; E: zreli sejalni plodovi. (Jendouba, SZ Tunizija; 22. 7. 2020). Fotografije: Ridha El Mokni.

\section{Martyniaceae particularity}

Bearing in mind that the entire body of the species belonging to Martyniaceae family was covered by numerous secretory hairs, the family was considered to be of "carnivorous plants" (Plachno et al. 2009, Rice 1999). Both taxa present in North Africa (Ibicella lutea and Proboscidea louisianica) are large/extending annual plants producing very sticky leaves and stalks, intended in catching and killing parasite bugs. But they do not produce any diges- tive enzyme and are called therefore "protocarnivorous" (ICPS 2020).

\section{Acknowledgements}

My thanks go to Ridha Aouni (University of Tunis ElManar, Tunisia) for his help in finding one of the three sites of Proboscidea louisianica.

Ridha El Mokni (D) https://orcid.org/0000-0003-3849-1039 


\section{References}

APD. 2020: African Plant Database (version 3.4.0). African Plant Database (version 3.4.0). Ibicella lutea (Lindl.) Van Eselt., Proboscidea louisianica (Mill.) Thell. - Genève: Conservatoire et Jardin botaniques Pretoria: South African National Biodiversity Institute. - Published at: https://www.ville-ge.ch/musinfo/bd/cjb/africa/recherche.php, Accessed: 24.7.2020.

APG IV. [Angiosperm Phylogeny Group IV] 2016: An update of the Angiosperm Phylogeny Group classification for the orders and families of flowering plants. Botanical Journal of the Linnean Society 181: 1-420.

Belkassam, A., Rebbas, Kh., Chelghoum, H., Ait Hammou, M. \& Miara, M. D. 2020: Découverte d'Ibicella lutea (Lindl.) Van Eselt en Algérie. Bulletin de la Société Royale des Sciences de Liège 89: 85 - 90 DOI: http://dx.doi.org/10.25518/0037-9565.9727

Bretting, P. K. 1983: The taxonomic relationship between Proboscidea louisianica and Proboscidea fragrans (Martyniaceae). The Southwestern Naturalist 28: 445-450.

Chelghoum, H., Ait Hammou, M., Miara, M. D. \& Fertout-Mouri, N. 2020: Solanum rostratum (Solanaceae): une nouvelle xérophyte invasive pour la flore d'Algérie. Flora Mediterranea 30: 81-86. DOI: http://dx.doi.org/10.7320/FlMedit30.081

Conca, A., Oltra, J. E. \& Serra, L. 2002: Proboscidea louisianica (Mill.) Thell. (Martyniaceae), nueva para la comunidad Valenciana. Flora Montiberica 22: 10-11.

Czerepanov, S. K. 1995: Vascular plants of Russia and adjacent states (the former USSR). Cambridge: Cambridge University Press.

Dobignard, A. \& Chatelain, C. 2012 : Martyniaceae. In : Index synonymique de la flore d'Afrique du Nord 4, p. 396. Genève. DOI: http://dx.doi.org/10.24310/abm.v45i0.5186

El Mokni, R. \& Domina, G. 2020: Additions to terrestrial flora of Tunisia: occurrence and taxonomic notes. Check List 16: 553-561. DOI: http://dx.doi.org/10.15560/16.3.553

El Mokni, R. \& Domina, G. 2018: Spirodela polyrhiza (L.) Schleid., Wolffia arrhiza (L.) Wimm. - Pp.197-198. In: Raab-Straube E. von \& Raus Th. (ed.) 2018: Euro+Med-Checklist Notulae, 9 [Notulae ad floram euromediterraneam pertinentes No. 38]. Willdenowia 48: 195-220. DOI: https://doi.org/10.3372/wi.48.48203

El Mokni, R. \& Iamonico, D. 2018a: A new record for the non-native flora of Tunisia, Eclipta prostrata (Ecliptinae, Asteraceae), and a note on the national status of Erigeron bonariensis, Lepidium didymum, and Symphyotrichum squamatum. Flora Mediterranea 28: 145-153. DOI: http://dx.doi.org/10.7320/FlMedit28.145

El Mokni, R. \& Iamonico, D. 2018b: Three new records of Senecioneae (Asteraceae) for the allochthonous Tunisian Flora. Flora Mediterranea 28: 385-392. DOI: http://dx.doi.org/10.7320/ FlMedit28.385

El Mokni, R. \& Iamonico, D. 2019: Bassia scoparia (Amaranthaceae s. 1.) and Sesuvium portulacastrum (Aizoaceae), two new naturalized aliens to the Tunisian flora. Flora Mediterranea 29: 191-196. DOI: https:// dx.doi.org/10.7320/FlMedit29.191

El Mokni, R. \& Iamonico, D. 2020: New aliens in Malvaceae for the North African flora, with nomenclatural notes. Collectanea Botanica 39: e009. DOI: https://dx.doi.org/10.3989/collectbot.2020.v39.009
El Mokni, R. \& Verloove, F. 2017: Ehrharta calycina Sm.- Pp. 299. In: Raab-Straube E. von \& Raus Th. (ed.) 2017: Euro+Med-Checklist Notulae, 8 [Notulae ad florameuro-mediterraneam pertinentes No. 37]. Willdenowia 47: 293-309. DOI: https://doi.org/10.3372/wi.47.47311

El Mokni, R. \& Verloove, F. 2019a: New records, distribution and taxonomic notes for non-native vascular flora of Tunisia - I. Poaceae. Flora Mediterranea 29: 45-53. DOI: http://dx.doi.org/10.7320/ FlMedit29.045

El Mokni, R. \& Verloove, F. 2019b: Cyperus alternifolius subsp. flabelliformis Kük. - Pp. 430-431. In: Raab-Straube E. von \& Raus Th. (ed.), Euro+Med-Checklist Notulae, 11 [Notulae ad floram euromediterraneam pertinentes No. 40]. Willdenowia 49: 421-445. DOI: https://doi.org/10.3372/wi.49.49111

El Mokni, R. 2018: Tradescantia fluminensis Vell., Tradescantia pallida (Rose) D. R. Hunt- Pp.199-200. In: Raab-Straube E. von \& Raus Th. (ed.) 2018: Euro+Med-Checklist Notulae, 9 [Notulae ad floram euromediterraneam pertinentes No. 38]. Willdenowia 48: 195-220. DOI: https://doi.org/10.3372/wi.48.48203

El Mokni, R. 2019: Melilotus officinalis (L.) Pall. - Pp. 434-435. In: Raab-Straube E. von \& Raus Th. (ed.), Euro+Med-Checklist Notulae, 11 [Notulae ad floram euro-mediterraneam pertinentes No. 40]. Willdenowia 49: 421-445. DOI: https://doi.org/10.3372/ wi.49.49111

El Mokni, R. 2020: Nicodemia madagascariensis (Lam.) R. Parker - Pp. 329-330. In: Raab-Straube E. von \& Raus Th. (ed.), Euro+MedChecklist Notulae, 12 [Notulae ad floram euro-mediterraneam pertinentes No. 41]. Willdenowia 50: 305-341. DOI: https://doi. org/10.3372/wi.50.50214

El Mokni, R., Elaissi, A. \& El Aouni, M. H. 2016 : Cuscuta campestris (Cuscutaceae) une holoparasite nouvelle et envahissante pour la flore de Tunisie. Flora Mediterranea 26: 179-189. DOI: http://dx.doi. org/10.7320/FlMedit26.179

El Mokni, R., Elaissi, A. \& Verloove, F. 2019: New succulents for the Tunisian and North African alien flora. Haseltonia 26: 68-77. DOI: http://dx.doi.org/10.2985/026.026.0110

El Mokni, R., Hamdi, N., De Belair, G. \& El Aouni M. H. 2012 : Découverte d'Ibicella lutea (Lindl.) Van Eselt. (Martyniaceae) en Kroumirie (Nord-Ouest de la Tunisie). Poiretia 4: 1-6.

El Mokni, R., Pasta, S. \& Pacifico, D. 2020: Amaryllis belladonna L. (Amaryllidaceae, Amaryllidoideae), first record as naturalized geophyte in Tunisia and continental North Africa. Hacquetia 19(2): 331-336. DOI: http://dx.doi.org/10.2478/hacq-2020-0011

Euro+Med Plantbase 2020: Ibicella lutea (Lindl.) Van Eselt., Proboscidea louisianica (Mill.) Thell. Euro+Med PlantBase-the information resource for Euro-Mediterranean plant diversity. http:// ww2.bgbm.org/EuroPlusMed/query.asp, Accessed: 24.7.2020.

Greuter, W., Burdet, H. M. \& Long, G. 1989: Med-Checklist. A critical inventory of vascular plants of the circum-Mediterranean countries. 4. - Genève: Conservatoire et Jardin botaniques de la Ville de Genève; Berlin: Secrétariat Med-Checklist, Botanischer Garten und Botanisches Museum Berlin-Dahlem.

Gutierrez, R. 2012: A phylogenetic study of the plant family Martyniaceae (order Lamiales). Ph.D. dissertation, Arizona State Univ., Tempe. 
Iamonico, D. \& El Mokni, R. 2020: Phymosia (Malvaceae) a new genus for the flora of Africa, with nomenclatural notes. Hacquetia 19(2): 325-330. DOI: http://dx.doi.org/10.2478/hacq-2020-0008

ICPS. 2020: The International Carnivorous Plant Society (ed.), https://www.carnivorousplants.org/grow/guides/DevilsClaw, Accessed: 24.7.2020

Ihlenfeldt, H. D. 2004: The Martyniaceae in: Kadereit J.W. (ed.), Flowering Plants. Dicotyledons: Lamiales (except Acanthaceae including Avicenniaceae). The Families and Genera of Vascular Plants, vol. 7. Pp. 283-288. Springer, Berlin, Heidelberg.

IPNI. 2020: The International Plant Names Index. Available at: http:// www.ipni.org/ipni, Accessed: 24.7.2020.

Jäger, E. J., Ebel, F., Hanelt, P. \& Müller, G. (ed.) 2008: Rothmaler Band 5. Exkursionsflora von Deutschland. Krautige Zier- und Nutzpflanzen. Springer Verlag, Berlin: 880 pp.

Knees, S. G. 2000: Martyniaceae. In: Cullen, J. et al. (ed.), The European Garden Flora, vol. 6. Cambridge University Press, Cambridge: $371-372$.

Le Bourgeois, T., Rodriguez, A., Véla, E., Marnotte, P. \& Fried, G. 2017 : Focus sur une espèce : Ibicella lutea (Lindl.) Van Eselt. Nouvelle observation d'une curieuse plante dans la Haute Garonne. Journal de Botanique 79: 53-55.

Le Floc'h, E., Le Houérou, H. N. \& Mathez, J. 1990: History and patterns of plant invasion in Northern Africa. In: Di Castri, F., Hansen, A. J. \& Debussche, M. (ed.). Biological invasions in Europe and the Mediterranean Basin. Kluwer Academic Pub. Dordrecht, pp. 105-133.

Mabberley, D. J. 2008: Mabberley's plant-book (3th ed.). Cambridge University Press, Cambridge: XVIII + 1021 pp.

Martín Madrigal, E. \& Fernández González, F. 2000: Proboscidea louisianica (Miller) Thell. (Martyniaceae) en España. Anales del Jardín Botánico de Madrid 58(1): 190-191.

Paiva, J., Herrero, A. \& Aedo, C. 2001: Martyniaceae. - Pp. 21-24 in Castroviejo S. et al. (ed.), Flora Iberica. Plantas vasculares de la Península Ibérica e Islas Baleares 14. Myoporaceae - Campanulaceae. Madrid: Real Jardín Botánico, C.S.I.C.

Plachno, B. J., Adamec, L. \& Huet, H. 2009: Mineral nutrient uptake from prey and glandular phosphatase activity as a dual test of carnivory in semi-desert plants with glandular leaves suspected of carnivory. Annals of Botany 104(4): 649-654. DOI: http://dx.doi.org/10.1093/ aob/mcp155

Pyšek, P., Richardson, D. M. \& Williamson, M. 2004: Predicting and explaining plant invasions through analysis of source area floras: some critical considerations. Diversity and Distributions 10: 179-187. DOI: https://doi.org/10.1111/j.1366-9516.2004.00079.x

Raab-Straube, E. von 2018+: [continuously updated]: Martyniaceae. In: Euro+Med Plantbase - the information resource for EuroMediterranean plant diversity. - Published at http://ww2.bgbm. org/EuroPlusMed/PTaxonDetail.asp?NameId=26346\&PTRef Fk=7500000, Accessed: 26.7.2020.

Raus, Th. \& Raabe, U. 2016: Proboscidea louisianica (Miller) Thell. In: Raab-Straube E. von \& Raus Th. (ed.): Euro+Med-Checklist Notulae, 6 [Notulae ad floram euromediterraneam pertinentes No. 35]. Willdenowia 46: pp. 429-430. DOI: https://doi.org/10.3372/ wi. 46.46310
Rebbas, Kh. 2020 : Découverte d'Ibicella lutea (Lindl.) Van Eselt. (Martyniaceae) en Kabylie (Béjaia, Algérie). Acta Botanica Malacitana 45: 153-156.

Rice, B. 1999: Testing the Appetite of Ibicella and Drosophyllum. Carnivorous Plants Newsletter 28(2): 40-43.

Richardson, D. M., Pyšek, P. \& Carlton, J. 2011: A compendium of essential concepts and terminology in invasion ecology. In: Richardson, D. M. (ed.). Fifty years of invasion ecology: the legacy of Charles Elton. Oxford: John Wiley \& Sons Ltd. pp. 409-420.

Sakhraoui, N., Chefrour, A. \& Metallaoui, S. 2019b: Naturalisation de Melia azedarach (Meliaceae) et premier signalement de Canna indica (Cannaceae) et Pelargonium zonale (Geraniaceae) en Algérie. Flora Mediterranea 29: 223-226. DOI: http://dx.doi.org/10.7320/ FlMedit29.223

Sakhraoui, N., Metallaoui, S. \& Chefrour, A. 2019a: Naturalisation d'Anredera cordifolia (Basellaceae) en Algérie. Flora Mediterranea 29: 159-162. DOI: http://dx.doi.org/10.7320/FIMedit29.159

Sevgi, E., Kizilarslan-Hançer, C., Yilmaz, H. \& Akkaya, M. 2017: A new alien species record for the flora of Turkey: Proboscidea louisianica (Miller) Thell. Eurasian Journal of Forest Science 5(2): 19-25. DOI: http://dx.doi.org/10.31195/ejejfs. 351280

Stànescu, I. 2009: Morpho-anatomical aspects of Proboscidea louisianica (Mill.) Thell. Scientific Annals of Alexandru Ioan Cuza: Section II a. Vegetal Biology 55: 65 - 73.

Sukhorukov, A. P., Kushunina, M., El Mokni, R., Nicola, M. G. A., Verloove, F., Uotila, P., Baider, C., Bruyns, P. V. \& Klak, C. 2019: Chorological and taxonomic notes on African plants, 4 : Caryophyllales. Botany Letters 166(4): 401-416. DOI: https://doi.org $/ 10.1080 / 23818107.2019 .1652848$

Sukhorukov, A. P., Kushunina, M., El Mokni, R., Sáez, G. L., El Aouni, M. H. \& Daniel, Th. F. 2018: Chorological and taxonomic notes on African plants, 3. Botany Letters 165(2): 228-240. DOI: https://doi.org/10.1080/23818107.2018.1465467

Sukhorukov, A. P., Martín-Bravo, S., Verloove, F., Maroyi, A., Iamonico, D., Catarino, L., El Mokni, R., Daniel, F. Th., Belyaeva, I. V. \& Kushunina, M. 2016: Chorological and taxonomic notes on African plants. Botany Letters 163: 417-428. DOI: https://doi.org/10. 1080/23818107.2017.1311281

The Plant List. 2020: Version 1.1. Published on the Internet; http:// www.theplantlist.org/, Accessed: 25.7.2020.

Thieret, J. W. 1976: Floral biology of Proboscidea louisianica (Martyniaceae). Rhodora 78(814): 169-179.

Verloove, F. 2020: Proboscidea louisianica (Mill.) Thell. In: Manual of the alien plants of Belgium. - Meise: Botanic Garden Meise. Published at http://alienplantsbelgium.be/content/proboscidea, Accessed: 26.7.2020.

Vilà, M., Meggaro, Y., \& Weber, E. 1999: Preliminary analysis of the naturalized flora of northern Africa. Orsis 14: 9-20.

Wetherwax, M. \& Heckard, L. R. 2012: Proboscidea louisianica subsp. louisianica, in Jepson Flora Project (ed.) Jepson eFlora, /eflora/eflora display.php?tid=52532, Accessed: 25.7.2020. 